\title{
På rejse med Virtual Reality i billedkunst - erfaringslæring gennem kombineret fysisk og virtuel modelbygning
}

\section{Gunver Majgaard}

\section{Lektor}

Mærsk Mc-Kinney Møller Instituttet, Syddansk Universitet.

\section{Patricia Lyk}

\section{Studerende}

Mærsk Mc-Kinney Møller Instituttet, Syddansk Universitet.
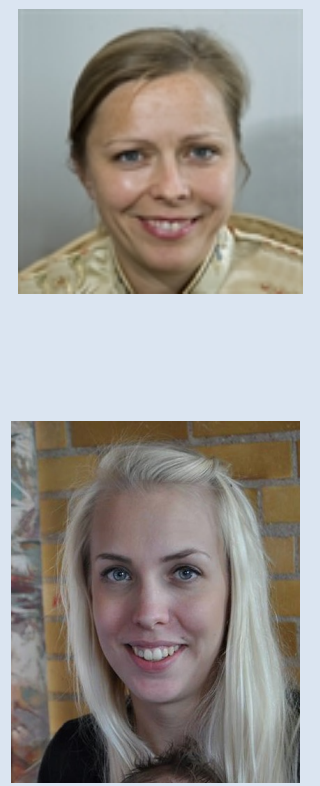


\section{Abstract}

Tema. Denne artikel udforsker de læringspotentialer, der opstår ved at lade elever fra 5. klasse deltage i designprocesser vedrørende rumlig modellering i fysiske og virtuelle medier i billedkunst. Eleverne udformede rumlige modeller i miniformat for derefter at besøge dem i den virtuelle verden i den størrelse, som de havde tænkt sig, de skulle have.

Fokus. I artiklen er der særligt fokus på hvordan læringscentrede designprocesser og Virtual Reality tilsammen kan understøtte erfaringslæring. Det er dermed elevernes læring i forbindelse med designprocesserne artiklen kredser om.

Konklusion. Eleverne fik en større forståelse af teknologi og kreative designprocesser ved at fungere som informanter og designpartnere $\mathrm{i}$ designforløbet. Eleverne fik igennem design af de fysiske modeller og besøget i Virtual Reality formidlet to oplevelser af deres modeller, som styrkede grundlaget for erfaringsbaseret læring. Erfaringsbaseret læring kombinerer oplevelse, refleksion, abstraktion og aktiv eksperimenteren i en proces, som transformerer oplevelse til viden.

\section{Abstract in English}

Theme. This article explores the learning potentials that arise by combining spatial modelling in physical and virtual media in a 5 th grade art class. The students created small scale three-dimensional models, and then visited them in the virtual world in the scale that they intended.

Focus. The main focus in the article is on how learning centered design processes and Virtual Reality combined can support experience based learning.

Conclusion. The students obtained a better understanding of technology and creative design processes by acting as informants and design partners in the design process. Through the design of the physical model and through the visit in Virtual Reality mediated, the students obtained two experiences of their models, which strengthened the foundation for experience based learning. Experience based learning combines experience, reflection, abstraction and experimentation in one process which transforms experience into knowledge.

\section{Indledning}

I denne artikel undersøges det, hvordan elever fra 5. klasse kan deltage i designprocesser med Virtuel Reality i form af Oculus Rift headsettet. Headsettet ligner en form for dykkerbrille, som når man tager den på "nedsænker" en i en virtuel tredimensional verden. Murray (1997) sammenligner den omsluttende Immersive Virtual Reality oplevelse med at være nedsunket og omsluttet af vand. Oculus Rift headsettet er desuden en 
slags wearable som opfanger brugerens hovedbevægelser og anvender disse til a navigere rundt i den virtuelle verden (Majgaard, 2014; Oculus Rift, 2015).

Virtuel Reality repræsenterer et lovende område med potentialer for at forbedre og forandre læringsoplevelsen. Det virtuelle miljø kan tilbyde en rig, interaktiv og engagerende læringskontekst som understøtter erfaringsbaseret læring igennem interaktive førstehånds oplevelser (Mantovani, 2003). Virtual Reality kombinerer den fysiske virkelighed, hvor vores kroppe er, med den virtuelle virkelighed skabt igennem teknologisk mediering. Vores følelse af tilstedeværelse og nærværd i dette blandede miljø er endnu ikke særligt udforsket i en læringssammenhæng (Waterworth og Riva, 2014).

Læringsperspektivet tager udgangspunkt i erfaringsbaseret og konstruktionistisk læring og koblingen mellem design, teknologi og læreprocesser (Kolb, 1984; Papert, 1980; Druin 2002). Vores perspektiv på erfaringsbaseret læring er inspireret af Kolb (1984), hvor læring forstås som en proces, hvor oplevelser og erfaringer transformeres til ny viden. Eleverne gennemløber i projektet en designcentret læreproces, hvor de oplever og erfarer igennem designprocessen. Druin $(1999 ; 2002)$ kobler design og læreprocesser. Hun har fokus på hvordan børn kan deltage aktivt i designprocesser, og at de kan indtage roller som $\mathrm{fx}$ meddesignere eller testere. Endvidere bygger vores læringsperspektiv på eksperimentelle og konstruktionistiske læreprocesser, hvor børn lærer mens de bygger og eksperimenterer sig frem understøttet af teknologi, som det beskrives af Papert (1980) med flere (Resnick, et al., 2009a \& 2009b; Ejsing-Duun, Karoff, 2015; Nielsen, Jessen, \& Bærendsen, 2008; Bertel \& Rasmussen, 2013; Blikstein, 2013; Majgaard, 2013; Majgaard, G. 2014; Majgaard, G. 2014; Majgaard \& Bertel, 2014; Majgaard, Hansen, Bertel \& Pagh, 2014; Larsen \& Majgaard, 2014; Majgaard, 2015).

I dette projekt udvikler eleverne sammen med deres lærer ideer som bearbejdes til tredimensionelle modeller i pap, flamingo, sand, grand og andre materialer af fx Grønland, pyramiderne, et berømt fodboldstadion og havets dyb. Modellerne indscannes, således at eleverne herefter kan udforske modellerne i den virtuelle verden. Dette giver børnene mulighed for at springe ned på havets bund eller udforske Grønland eller pyramiderne. Børnene får herigennem konkrete og nye erfaringer med rumlige modeller både i den fysiske og virtuelle verden. Derudover får de erfaring med kreative designprocesser og egenproduktioner i den fysiske og virtuelle verden.

Ifølge fællesmål og læseplan for billedkunst i 3. - 5. klasse skal eleverne kunne skitsere og eksperimentere med små tredimensionelle rum. Det kan 
eksempelvis være modeller, installationer og tableauer, der har betydning for mennesker uden at have en praktisk funktion (Læseplan for faget billedkunst, 2015). Derudover skal eleverne arbejde med billeder i den digitale verden og anvende disse til præsentationer i en tværfaglig sammenhæng. Eleverne skal desuden ifølge fællesmålene være målrettede kreative producenter både i den fysisk og virtuelle verden (Fællesmål, 2015).

I artiklen undersøges følgende spørgsmål: Hvordan kan designbaserede læreprocesser og Virtual Reality tilsammen understøtte billedkunst i 5. klasse? - hvilke særlige kvaliteter opstår i læreprocessen?

For at kunne besvare spørgsmålet introducerer vi den digitale platform Oculus Rift, og hvordan Virtual Reality har været anvendt i andre og lignende sammenhænge. Dernæst redegør vi for vores forståelse af Virtual Reality med udgangspunkt i tre forskellige niveauer at tilstedeværelse i den fysiske og medierede verden (Waterworth og Riva, 2014). Derefter beskrives den læringscentrerede designproces med illustrative eksempler fra faserne: for-analyse, ideudvikling, udvikling af fysiske prototyper, test i Virtual Reality og evaluering. Efterfølgende diskuteres de illustrative eksempler i relation til tilstedeværelse i den fysiske og virtuelle verden, koblingen mellem disse, og hvordan dette kan stimulere læreprocessen i lyset af vores læringsperspektiv. Desuden diskuteres potentialer, udfordringer og perspektiver for anvendelsen af virtuel Reality i billedkunsttimerne.

\section{Den digitale platform: Immersive Virtuel Reality med Oculus Rift}

Virtual Reality kan defineres som en computer-genereret simulation af den virkelige eller forstillede verden (Mantovani, 2003). Simulationen præsenterer en tredimensionel verden ved hjælp af et visuelle og auditive input. For at få den optimale fordybende oplevelse må brugeren kunne interagere med dele af kroppen, hvilket straks får den virtuelle verden til at reagere. Fx, når man drejer hovedet i den fysiske verden, så panorerer man tilsvarende i den virtuelle verden. Når man bevæger kroppen naturligt og ser ind i en tredimensionel virtuel verden er der grundlag for intens fordybet oplevelse, der omtales også som Immersive Virtual Reality (Salen og Zimmerman 2004, Mantovani, 2003; Waterworth og Riva, 2015; Murray, 1997). I praksis opererer man dog oftest kun med hovedbevægelser, hvis man fx skal tage et skridt frem i den virtuelle verden, så må man tage tastaturet til hjælp.

Allerede i 1980'erne og 1990'erne var der interesse for Virtuel Reality, og der blev gennemført mange eksperimenter i forbindelse med undervisning, kunst og psykoterapi (Waterworth og Riva, 2015). Immersive Vitual Reality 
nåede dengang aldrig rigtig de almindelige forbrugere. I dag er Immersive Virtual Reality i form af Oculus Rift inden for rækkevidde, og det er netop Oculus Rift som anvendes i dette projekt.

Oculus Rift er et Virtuel Reality headset, som til forveksling ligner en dykkermaske. Indvendigt har headsettet monteret en todelt fladskærm med opløsningen $640 \times 800$ pr. øje i development kit 1 , som blev anvendt i dette projekt. Skærmopløsningen kan godt virke lidt grovkornet som på en ældre computerskærm. Sensorer i form af accelerometer, gyroskop og magnotometer gør det tilsammen muligt konstant at registrere brugerens hovedposition (Oculus Rift Development Kid, 2013). Data fra sensorerne sendes via ledning til en computer, hvor de bruges til at beregne de rigtige vinkler på den 3D verden, som vises i de to skærme. Der generes to forskellige perspektiver, hvilket medvirker at der skabes en illusion af dybde. Der kan forekomme mindre forsinkelser mellem hoveddrejning og virtuel panorering hvilket kan give anledning til "cyber-sickness" (søsyge/kvalme).

Udover Oculus Rift anvendes programmet Blender til udarbejdelse af virtuelle 3D-figurer (Blender, 2014). Unity anvendes, som er en spil-engine til udvikling et interaktivt 3D-miljø, hvor de virtuelle 3D-figurer placeres (Unity, 2014; Unity, 2013).

I øvrigt er der siden gennemførslen af projektet udviklet en særlig papbrille ved navn Google Cardboard (Google Cardboard, 2015) til almindelige smartphones, som kan emulere Immersive Virtual Reality - ligesom Oculus Rift, dette vil gøre anskaffelsespriser til fremtidige skoleprojekter endnu billigere.

\section{Virtual Reality og tilstedeværelse}

Begrebet immersion diskuteres til stadighed, og forbindes med opslugende tilstedeværelse og brugerens oplevelse med den virtuelle verden (Salen og Zimmerman, 2004; Waterworth og Riva, 2015; Murray, 1997; Bolter \& Grusin, 2000). Murray (1997) sammenligner immersion med at være nedsænket i vand og dermed omsluttet af oplevelsen:

\footnotetext{
"Immersion is a metaphorical term derived from the physical experience of being submerged in water. We seek the same feeling from a psychologically immersive experience that we do from a plunge in the ocean or swimming pool: the sensation of being surrounded by a completely other reality, as different as water is from air, that takes over all of our attention, our whole perceptual apparatus."
}

(Murray, 1997, s. 98) 
Murray fokuserer desuden på "active creation of belief", hvor brugeren forhandler visse regler med den fiktive verden og aktivt accepterer at opføre sig som om de fiktive elementer var sande. Brugeren ved at han/hun bliver forført og "taber" ikke sig selv i verdenen.

Immersion er ofte et designmål i forbindelse med design af produkter til virtual Reality. Immersiv-interaktion med det virtuelle medie skal være så umiddelbar, naturlig og transparent at brugeren glemmer teknologien, hvilket ofte står i modsætning til det voldsomme apparatur brugeren skal iklædes (Bolter \& Grusin, 2000; Dourish 2002). Man må desuden ofte bruge tastatur eller Joystiks for at berige interaktionen. Bolter \& Grussin (2000) beskriver desuden den virtuelle verden som et hypermedium, hvor de visuelle scenarier er menneskeskabte illusioner, som kan være grovkornede skitser eller fantastiske som reneseancemalerier, hvor der leges med perspektiver og former, og hvor man hurtigt bevæge sig mellem forskellige virtuelle rum og repræsentationer.

Fornemmelsen af at føle sig til stede er essentiel for en troværdig Immersive Virtuel Reality oplevelse. At være til stede kan beskrives i modsætning til at være fraværende. Man kan godt være fysisk tilstede og samtidig mentalt fraværende. For at fungere effektivt skifter vores opmærksomhed hele tiden mellem den ydre verden og indre private verden med tanker, planer, erfaringer og minder. Evnen til at mærke forskellen og være det "rigtige sted" er følelsen af tilstedeværelse (Waterworth og Riva, 2015, s. 3).

Waterworth og Riva (2015) skelner mellem to trends inden for computermedierede miljøer: blandet virkelighed (Blended Reality) og virtuel virkelighed (Virtual Reality). Til daglig befinder vi os i en slags blandet virkelighed, hvor vi samtidig er til stede både på digitale medier og den fysiske verden (Waterworth og Riva, 2015; Tuckle, 2010). Det kan være når vi er opslugte af vores smartphones eller en film vi streamer på tv'et og samtidig af praktiske gøremål fx børnepasning. Det kan også bogstavelig talt være mere blandet, som når man lægger et virtuelt lag oven på virkeligheden, dette benævnes Augmented Reality (Waterworth og Riva, 2015; Wiki Augmented Reality, 2015). Et eksempel herpå er en kompasnål kædet sammen med telefonens kamera (Augmented Reality Apps, 2015). Der er desuden nye og lovende Augmented Reality produkter i støbeskeen fx brillen Hololens (Microsoft Hololens, 2015).

Waterworth og Riva (2015) graduerer fornemmelsen af kognitive tilstedeværelse på tre niveauer i relation til Virtuel Reality (Waterworth og Riva, 2015 s. 10-25): 
(1) Fysisk proprioceptiv tilstedeværelse, som bygger på at være i stand til sensomotorisk og kropsbevidst at opfatte ens nærmeste omgivelser, orientere sig og bevæge sig i forhold til dette, fx at gå op af en trappe uden at spekulere over hvordan, eller føre en kop til munden uden at tænke over om koppen nu også rammer munden.

(2) Kerneopfattelse/kerneforståelse af tilstedeværelse, bygger på hvordan man opfatter sig selv i forhold til sine stadigt skiftende omgivelser, hvilket også bygger på ens erfaringer, fx spontant at returnere en vildfaren bold, som tilfældigt kommer ens vej på en gåtur i parken. Kerneselvet er en flygtig bevidst enhed som uophørligt skabes og genskabes i ens interaktion med omverdenen.

(3) Udvidet reflekteret tilstedeværelse, bygger på bevidst at sætte sig mål og fokusere på at nå dem. Fx når man skal afgøre en vigtig fodboldkamp på straffespark. Denne type reflekteret tilstedeværelse, kan påvirke gennemførslen af sparket.

Fornemmelsen af tilstedeværelse forstærkes når alle tre niveauer integreres i en konkret fysisk, blandet eller virtuel virkelighed (Waterworth og Riva, 2015, s. 18). Hvis der en konflikt mellem indholdet af niveauerne vil tilstedeværelsesfornemmelsen forringes. Hvis det tredimensionelle billede ikke helt kan følge med når man drejer hovedet vil der være en konflikt på niveau 1 og 2 . Ens kropsbevidsthed (niveau 1) bliver udfordret og det fører til at man føler sig lidt utilpas (niveau 2) som ved køresyge altså her "cyber-sickness".

I forbindelse med projektet vil vi særligt undersøge på hvilke niveauer eleverne stimuleres.

\section{Virtual Reality i en undervisningssammenhæng}

Herunder beskrives udvalgte eksempler på Virtual Reality anvendt i en undervisningssammenhæng.

Fysik simulator. Brelsford gennemførte et succesfuldt forsøg med en fysik simulator designet til at give studerende en bedre intuition omkring fysik (Allison D. og Hodges, 2000). Eleverne fik, i systemet, et pendul og tre kugler med varierende masse. I systemet kunne eleverne manipulere med tyngdekraften, luftmodstand, friktion og flere begyndelsesbetingelser.

Et andet eksempel på er "The Virtual Reality Gorilla Exhibit" (Allison D. og Hodges, 2000). Systemet blev udviklet i samarbejde med Zoo Atlanta, hvor eleverne opleve gorillaernes adfærd, levested, sociale interaktioner og indbyrdes strukturer.

CyArk er en organisation, som digitalt bevarer historiske bygningsværker rundt om i verden fx Chichén Itzá, Pompei, Rapa Nui, Babylon og Mount Rushmore (Kacyra, 2015). CyArk stiller de scannede modeller og andet 
undervisningsmateriale til rådighed til undervisningsbrug. Det vil være oplagt i en dansk kontekst at inddrage disse modeller i fx historieundervisning eller billedkunst.

\section{Metode og beskrivelse af fremgangsmåden}

Udforskningen af Immersive Virtual Reality i 5. klasse er inspireret af Druins ideer om elevcentrerede designprocesser, som Druin $(1999 ; 2002)$ benævner Cooperative Inquiry. Cooperative Inquiry er en tilgang til forskning, der omfatter tre aspekter (Druin, 1999):

(1) Flerfagligt partnerskab mellem børn, underviser og forsker;

(2) Feltforskning i elevernes skoleomgivelser hvor teknogien skal anvendes og som bidrager til forståelse kontekst, aktiviteter og artefakter;

(3) Iterativ udvikling af lav- og højteknologiske prototyper.

Flerfagligt partnerskab med brugere herunder børn kræver her, ifølge Druin, nogle andre/ekstra overvejelser idet børn, ikke tænker eller arbejder på samme måde som voksne. At arbejde designorienteret med børn kræver en særlig forståelse af børn som en del en unik børnekultur (Druin, 2002; Jessen 2003). Børn kan desuden have flere forskellige roller i designprocessen $\mathrm{fx}$ bruger, tester, informant og designpartner, dette gør sig også gældende i dette projekt.

Igennem feltforskning opnås en forståelse for brugerens behov igennem de aktiviteter og artefakter, der er en del af brugerens kontekst (Druin, 2002). Denne forståelse er især vigtigt, når der arbejdes med børn, da børn, ifølge Druin, ikke har ligeså nemt ved at udtrykke deres behov som voksne. Dette synspunkt kritiseres hun for af Ole Sejer Iversen og Christina Brodersen. De mener, Druin er (for) Piaget-inspireret i sin betragning af børn, der bl.a. omtales som "cognitive incomplete" og "humans-becomings"(Iversen og Bordersen, 2006).

Druin nævner desuden, at det er en fordel med en "interactor" under processen. En interactor er en voksen, der ligger op til diskussion og stiller spørgsmål til aktiviteterne, imens de foregår, men på en "ikkeinterviewende" måde. Ud fra disse data kan der opstå idéer, man gerne vil prøve af eller temaer, som man i teamet gerne vil undersøge nærmere.

Det sidste aspekt iterative udvikling af lav- og højteknologiske prototyper, fx papir -"mock-ups" eller Wizard of Oz-modeller. Der opfordres her til at designteams, på tværs af alder og baggrund, visualiserer deres ideer igennem prototyper. Ifølge Druin kan det være svært for børn at kommunikere deres ideer til voksne, men prototyping tilbyder en konkret måde at diskutere ideer på. Igennem flere iterationer opstår til sidst hightech prototyper. 
Det der udvikles i dette projekt et undervisnings-design med anvendelse af Virtual Reality i billedkunstundervisningen. Designprocessen er opdelt i følgende faser: Forundersøgelse, idegenerering, prototyping og evaluering. Eleverne og deres lærer deltager i alle faser og i hver fase er der en eller flere interventioner i klassen på skolen. Empiriindsamling sker igennem feltforskningsmetoden dvs. observation, åbne kvalitative interviews, elevproduktioner og fotos. Forskerens rolle er at være "interactor", interviewer, observatør, teknisk ekspert, designekspert og hjælpelærer under udformningen af prototyper. Highlights fra designprocessen er udvalgt i relation til hvordan eleverne inddrages i den læringscentrerede designproces og hvordan medierne kombineres.

\section{Highlights fra forunders $\emptyset$ gelsen}

Forundersøgelsen fandt sted på elevernes skole og bestod at tre aktiviteter: Gruppearbejde med efterfølgende uformelt interview af eleverne; uformelt interview med underviseren og test af den teknologiske platform med eksisterende program. Formålet med forundersøgelsen var at få en bedre forståelse af eleverne, læreren og deres indtryk af Oculus Rift.

Elevernes deltagelse som informanter og designpartnere i for-analysen: Gruppearbejdet i klassen omhandlede hvilken type undervisning eleverne bedst kunne lide, hvad de syntes var kedeligt, hvordan de arbejdede med teknologi i dagligdagens undervisning. Eleverne fremhævende særligt temadage og emneuger, hvor de ikke bare sad og regnede opgaver, men hvor de fx tog ud og fotograferede geometriske former, som de så siden kategoriserede. Eller når de en sjælden gang tog på udflugt, fx når de i de mindre klasser nogen gange var i skoven eller nede og fiske ved en sø og lærte om det, de fandt. De fortæller også, at de en gang har cyklet til udsigten i Vissenbjerg efter de havde hørt og læst om istiden(Afgrunden, 2006). Vedrørende anvendelse af teknologi fremhævede de informationssøgning og en emneuge med LEGO Mindstorm.

Eleverne tester Oculus Rift: Slutteligt blev eleverne introduceret til Oculus Rift. Tre af eleverne i klassen, 3 drenge, havde allerede hørt om Oculus Rift og set videoer om headsettet på youtube.com. De virkede meget begejstrede for at skulle prøve Oculus Rift og forklarede meget præcist for de andre elever, hvad headsettet kunne. Eleverne fik vist headsettet og fik forklaret, at sensorer konstant måler, hvor ens hoved er og laver skærmbilleder ud fra det, og at man derfor kan få følelsen af at være inden i computerspillet. De blev desuden gjort opmærksomme på muligheden for "cyber-sickness". Eleverne prøvede simulationen Lorry Rider, som er en rutsjebanesimulation, der foregår i en kulmine (Lorry Rider, 2013). 

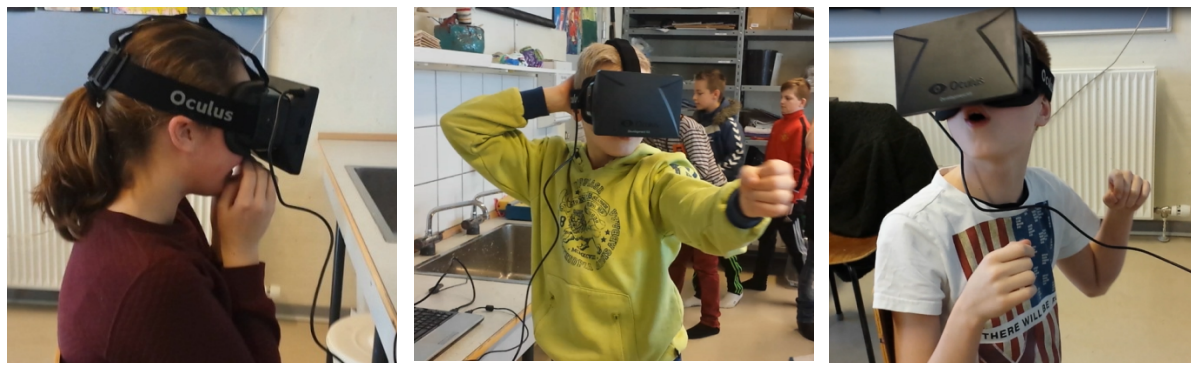

Figur 1 Eleverne afprøver Lorry Ride

Resultater af brugertesten, se Figur 1 herover: Eleverne udnyttede fint funktionen med at kigge rundt og flere drejede sig helt om for at kigge bagud. Nogle af eleverne beskrev undervejs for de andre, hvad de så, nogle kom med små hvin og lyde som "Wooow" og "Wiiiii" og kommentarer som "Orgh, den er fed", "Ad, hvor er det klamt" og "Arhhh, der er lava", mens andre var helt stille. Stort set alle eleverne levede sig hurtigt ind $\mathrm{i}$ simulationen: nogle holdte godt fast i stolen, de sad på, andre lænede sig til siderne i svingene i rutsjebanen og nogle rakte hænderne frem for at tage fat i noget i simulationen (som Figur 1 midt). En elev mente ligefrem, at han kunne mærke varmen fra lavaen i simulationen i virkeligheden. Ingen af eleverne tog headsettet af under simulationen, selvom 4 ud af 13 elever bagefter svarede ja til, at de havde fået kvalme, mens de havde det på.

Efterfølgende blev eleverne kort spurgt ind til deres oplevelse: "Man er rigtig inden i spillet" og "Sådan nogle briller ville jeg gerne have". Der blev også spurgt ind til, hvilke spil, man kan få til headsettet, og hvor det kan købes. En enkelt elev (en af de drenge, der i forvejen kendte til Oculus Rift) nævnte at billedet var "en smule utydeligt". Eleverne var meget interesserede i at prøve andre "spil".

Evaluering af foranalysen: Både elever og lærer var interesserede i at gå videre med teknologien og en cooperativ designproces. I samspil med læreren blev det besluttet fortsat at anvende billedkunsttimerne til at udvikle 3D-figurer og så efterfølgende scanne dem ind til senere brug for Oculus Rift.

\section{Idégenerering med mindmapping}

Formålet med denne fase var at udvikle ideer og temaer til hvordan Oculus Rift kunne bruges i undervisningen i folkeskolen. Eleverne fik desuden en kort introduktion til de kommende faser i udviklingsforløbet. De fik forklaret, hvordan selve processen ville komme til at foregå og at prototyperne skulle bygges i fysiske 3D-modeller, da de ellers ikke senere ville kunne scannes ordenligt ind på computeren. 
Elever som informanter og designpartnere: Eleverne startede med idégenerering, så vidt muligt i samarbejde med læreren, da hun vil være sekundær bruger af et endeligt produkt. Druin nævner desuden, at det kan være en fordel at inddrage lærere, da de, grundet deres førstehåndserfaringer i klasseværelset, er gode til indsamling af data og at det er vigtigt at opbygge et multidisciplinært partnerskab (Druin, 2002). I grupperne snakkede og diskuterede eleverne idéer til, hvad Oculus Rift kunne bruges til i undervisningssammenhæng, se Figur 2 herunder. Herefter præsenterede hver gruppe, deres bedste idéer for klassen.

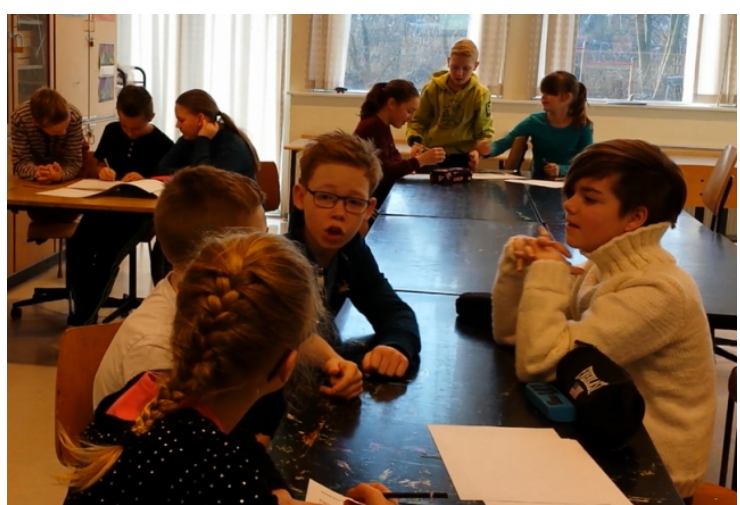

Figur 2 Brainstorm og mindmapping i en af grupperne

Herunder ses 2 eksempler på mindmaps, som eleverne fremstillede, se Figur 3.

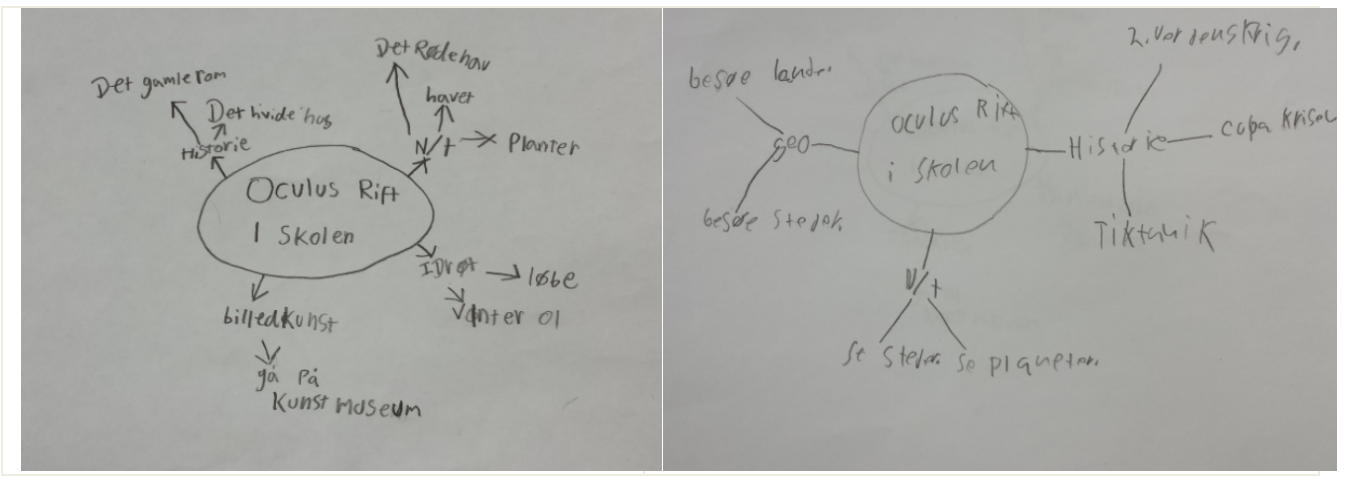

Figur 3 Mindmaps lavet i grupperne

Eleverne var enige om, at Oculus Rift ville være meget brugbart i geografi, historie samt natur og teknik. I historie og geografi kunne de se muligheden $\mathrm{i}$, at man kunne "besøge" steder fra undervisningen, som de ellers kun normalt ville se på billeder eller måske i film. I historie blev bl.a. nævnt steder som: det Hvide Hus og det gamle Rom, som det ses på Figur 3 til 
venstre, og Titanic og 2.-verdenskrig, som det ses på Figur 3 til højre. I geografi kunne man besøge andre lande og steder (Figur 3 til højre). I natur og teknik undervisningen kunne man, ifølge eleverne, besøge det Røde Hav, dykke i havet, se planter tæt på (Figur 3 til venstre) og besøge planeter som Mars (Figur 3 til højre). Det blev også foreslået, at man kunne bruge Oculus Rift i billedkunst, hvor man så kunne gå på kunstmuseum (Figur 3 til venstre). Eleverne diskuterede også, om man kunne bruge headsettet $\mathrm{i}$ hjemkundskab, hvor man så skulle lave fiktivt mad efter en opskrift, men blev enige om, at det ikke ville gøre noget godt for undervisningen, men kun gøre det kedeligere. To grupper diskuterede også, om Oculus Rift kunne bruges i idræt. En af idéerne her var, at man skulle løbe væk fra en flok zombier eller en vred idrætslærer og dermed blive tvunget til at løbe hurtigere og længere. En af eleverne, der kendte Oculus Rift i forvejen, forklarede de andre, at det kunne man ikke endnu med Oculus Rift, fordi den kun kunne måle på ens hoved og ikke ens fødder, og at headsettet havde brug for at være tilsluttet computeren med en ledning. En anden gruppe nåede frem til, at Oculus Rift kunne bruges i idræt til fx at se vinter OL, lave udspring eller se fodbold på stadion.

Da forslagene var blevet diskuteret på klassen stod det klart, at der specielt var 5 idéer, som både var realistiske indenfor tidsrammen, realistiske at fremstille og som eleverne kunne tænke sig at arbejde videre med. Det drejede sig om Grønland, Egypten (især pyramiderne), havet, Allianz Stadion og afgrunden i Vissenbjerg, der skulle fortælle noget om istiden i Danmark.

\section{Prototyping af fysiske 3D modeller}

De 3 efterfølgende uger arbejdede børnene, i samarbejde med underviseren på prototyperne. Eleverne var delt i 4-5 grupper, som hver arbejdede med deres emne. Læreren var på skift rundt i de forskellige grupper for at deltage i designprocessen ved bl.a. at diskutere idéer og komme med input, se Figur 4 herunder.
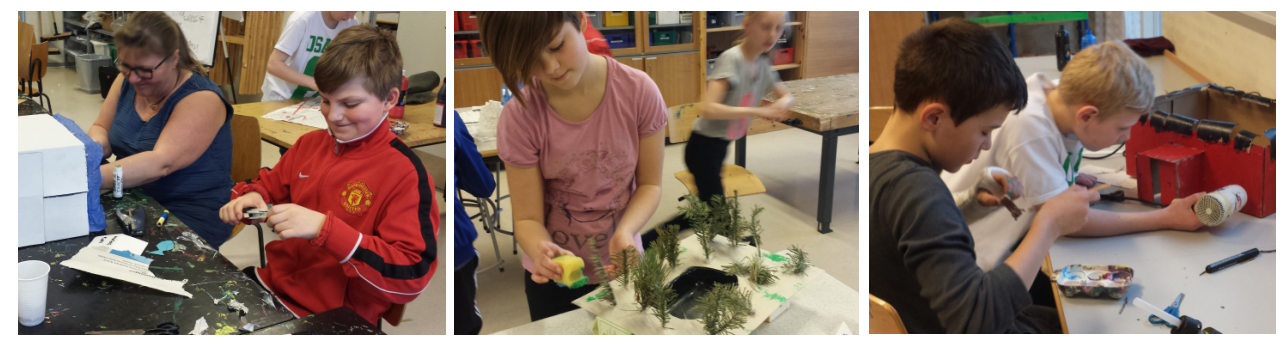

Figur 4 Der arbejdes intenst med prototyperne i grupperne

Elever som designere og læreren som "interactor". Eleverne fik forklaret, at de prototyper, de lavede skulle være med i et "spil", der skulle bruges til 
Oculus Rift. Der blev fra start arbejdet meget seriøst med prototyperne. Nogle elever lånte - på eget initiativ iPads på skolens bibliotek, og nogle brugte deres smartphones til at samle info om det, de byggede. De arbejdede meget koncentreret og diskuterede ofte indbyrdes i grupperne, hvordan tingene skulle udformes. Læreren nævnte, at der blev arbejdet bedre end normalt. Når læreren kom forbi grupperne, kom hun med input og idéer, som diskuterede med eleverne og kom frem til fælles løsninger og hjalp også med noget af det praktiske.

Herunder (Tabel 1) ses billeder af de endelige 3D-prototyper:

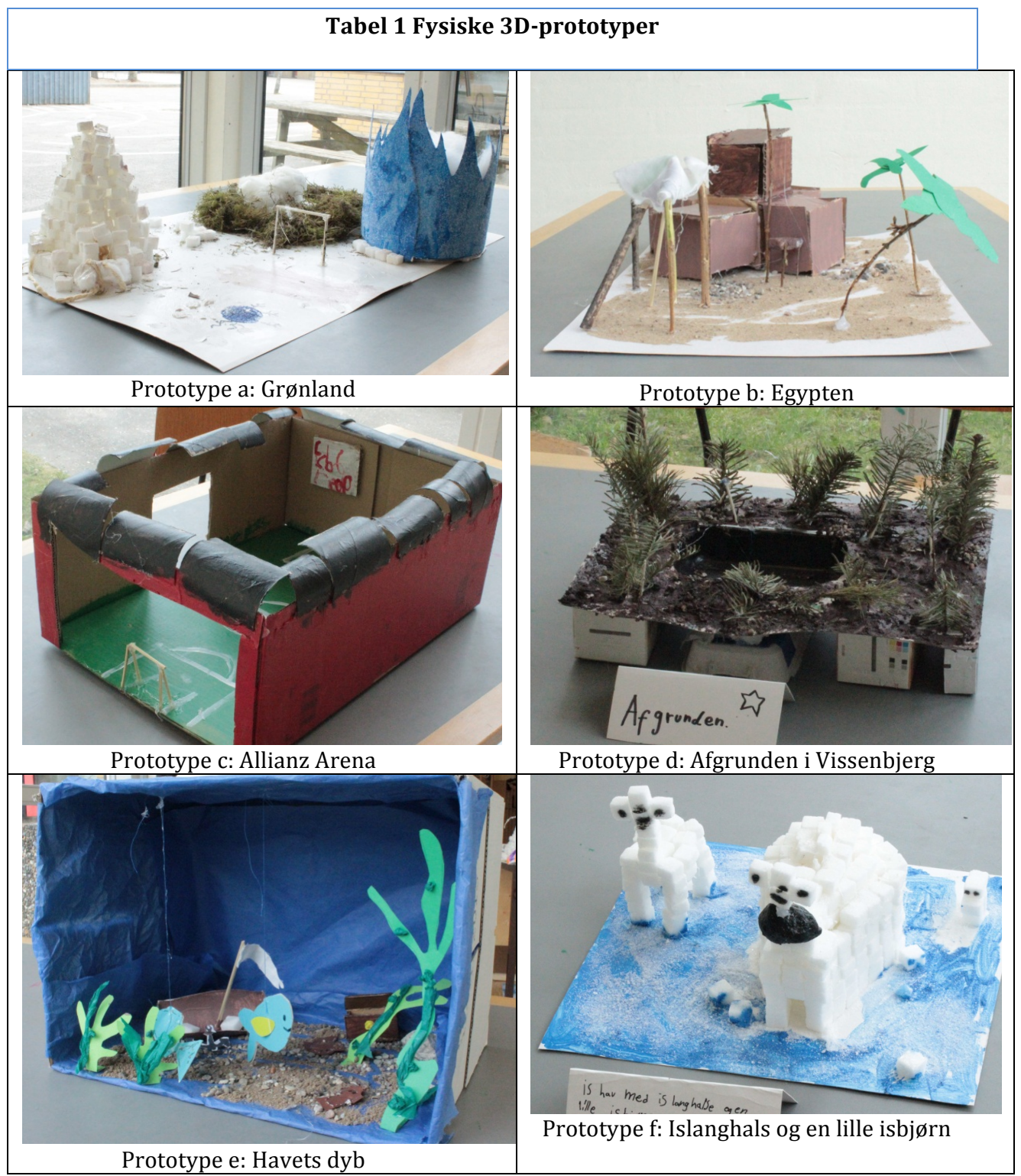

Første prototype er af Grønland (Tabel 1: prototype a). Eleverne fortalte, at de havde arbejdet med Grønland i skolen i en emneuge og at de godt kunne 
tænke sig at "besøge" Grønland med Oculus Rift, nu hvor de ikke kunne gøre det i virkeligheden.

Næste prototype er af Egypten (Tabel 1: prototype b). Eleverne i denne gruppe mente, det ville være sjovt og lærerigt at kunne besøge en pyramide og gerne kunne gå indeni den. Dette var dog ikke muligt at vise på prototypen.

En enkelt elev byggede Allianz Areana (Tabel 1: prototype c), da han gerne ville kunne opleve alle fodboldkampe på stadion, og det mente han Oculus Rift ville være perfekt til. Da der ikke var andre elever, der var med på idéen, byggede han alene (og sammen med læreren).

En anden gruppe byggede en prototype på Afgrunden i Vissenbjerg (Tabel 1: prototype d; Afgrunden, 2006)). En pige fra gruppen fortalte, at de før havde arbejdet med istiden og var cyklet op til Afgrunden og Udsigten i Vissenbjerg, fordi disse steder var gode eksempler på, hvordan istiden havde formet landskabet. En dreng tilføjede "og det er jo ikke alle skoler, der bare kan besøge afgrunden ligesom os."

Den næste prototype er af havet (Tabel 1: prototype e). Den blev lavet, fordi eleverne i denne gruppe havde et ønske om selv at kunne svømme rundt og udforske havet forskellige steder i verden.

Den sidste prototype (Tabel 1: prototype f) er lavet af to elever, der var med i gruppen, der ville lave Grønland. De endte dog med at arbejde alene. De har lavet en lille isbjørn og to "is-langhalse" (de havde fornylig arbejdet med dinosaurer).

\section{Prototyperne omsættes til den Virtual Reality og testes}

Prototyperne moduleredes op i Blender og overfladerne blev udarbejdet ud fra fotografier af prototyperne. I Unity blev der oprettet en 3D-verden, hvor figurerne blev indarbejdet. For at få Unity verdenen til at fungere med Oculus Rift anvendtes en særlig hjælpefil.

3D figurerne er alle anbragt i samme verden/scene i Unity, da det gør det en del nemmere ikke at skulle skifte mellem prototyperne, når alle 14 elever skal afprøve simulationen.

Der er anbragt en ekstra pyramide i baggrunden, som ikke er lavet ud fra børnenes prototyper (se Tabel 2 Screen dump b). Pyramiden er moduleret ud fra målene på Keopspyramiden, som to af eleverne fra klassen har besøgt i virkeligheden. Den ene elev nævnte under brainstormen at Oculus Riften kunne bruges til at få en idé om, hvor store pyramider er i 
virkeligheden, for det havde nemlig overrasket ham, da han besøgte Keopspyramiden. Øjenhøjden på playercontrolleren er indstillet til en personhøjde på $150 \mathrm{~cm}$, da det stemte meget godt overens med elevernes højde. Oplevelsen af pyramidens størrelse med Oculus Riften skulle derfor, teoretisk, give et godt billede af størrelsen på den virkelige pyramide.

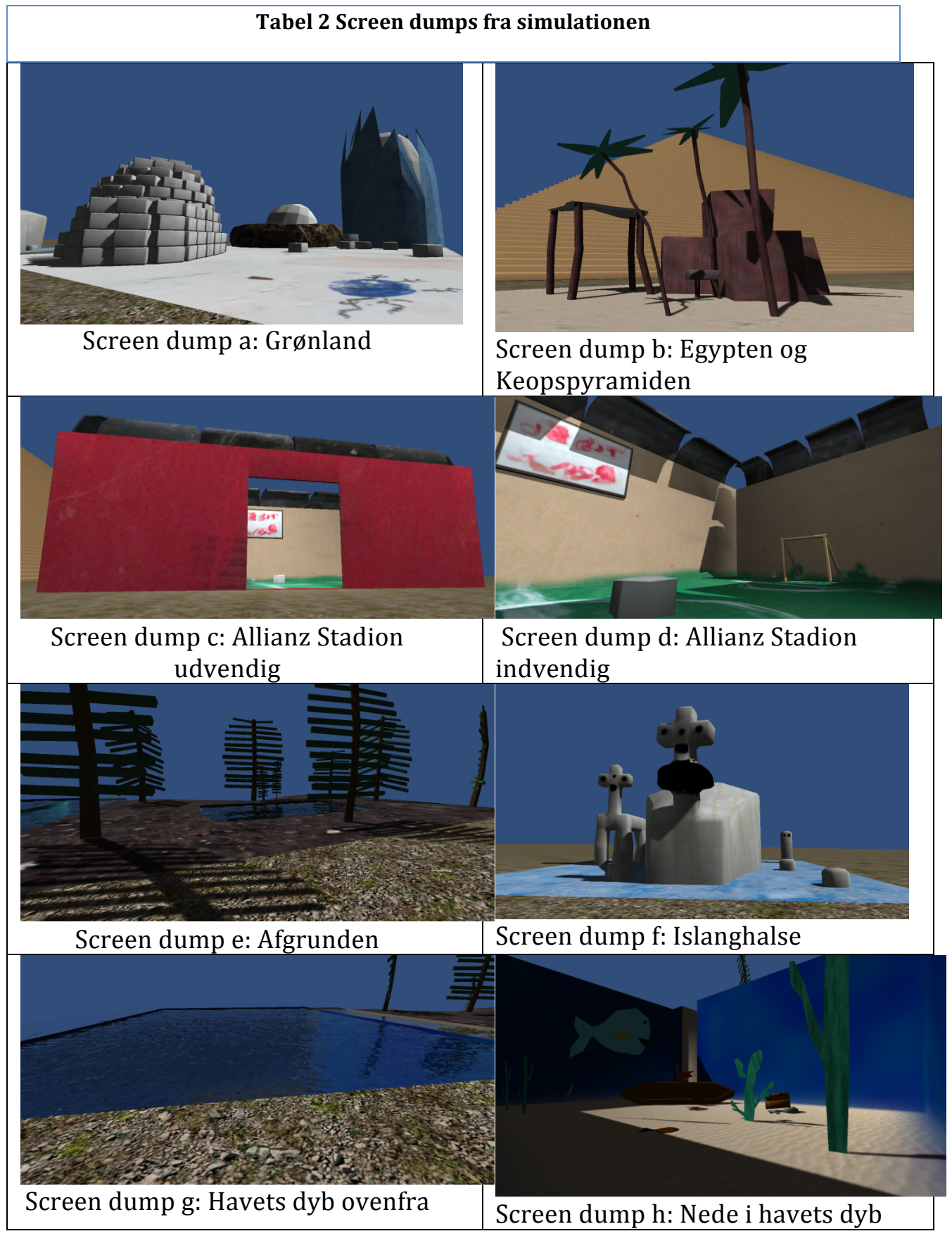

Evaluering i form for brugertest med elever: Oculus Riften og simulationen var sat op i et andet lokale end det, eleverne havde undervisning i og 
eleverne kom ind gruppevis og prøvede simulationen, se nedenstående Tabel 3.

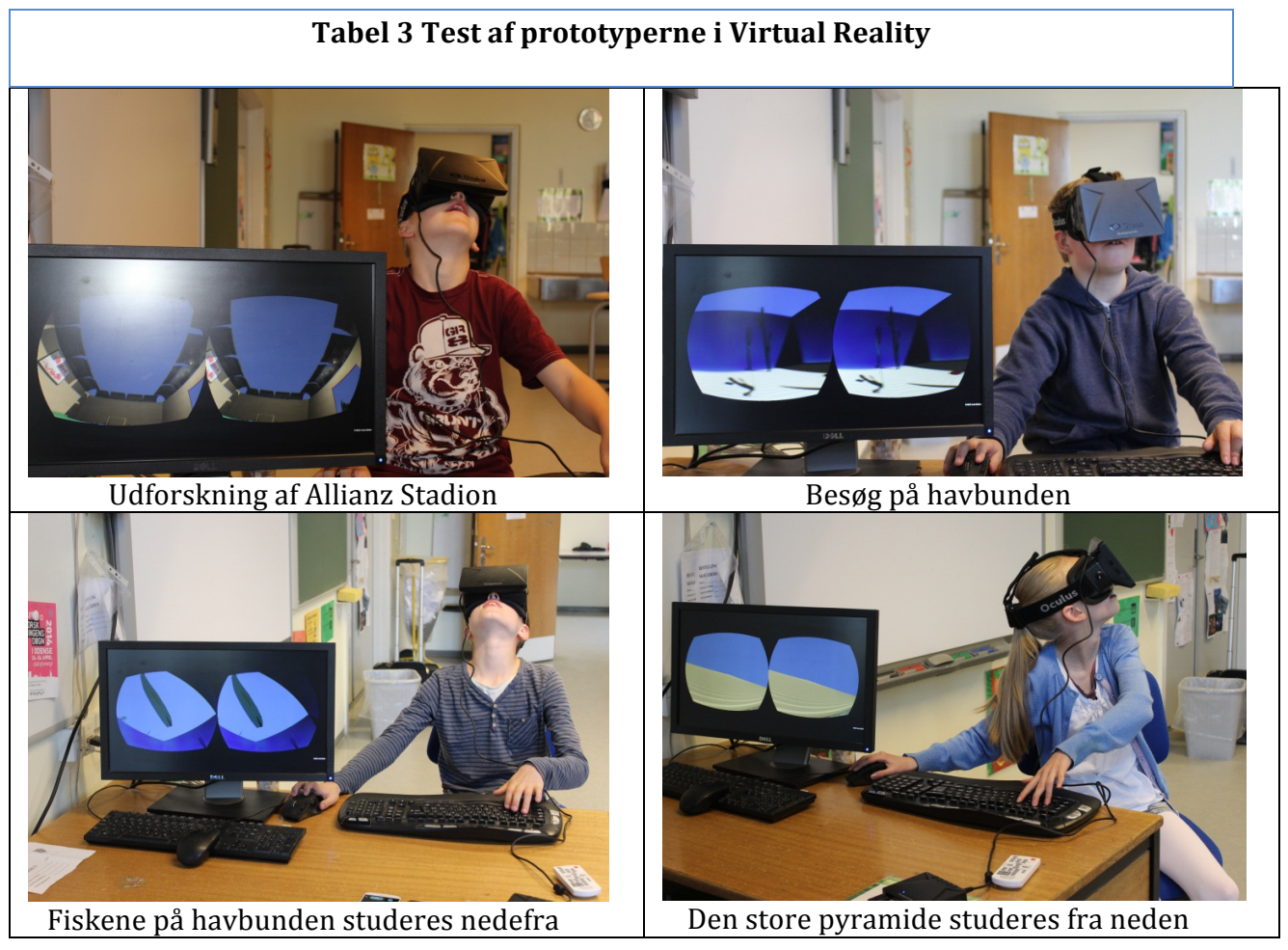

Eleverne beherskede styringen i simulationen fint, når de først havde fundet de rigtige taster. Det virkede af og til, som om eleverne var bundet og begrænset af tastatur og mus, da det ikke var lige til at finde taster og mus igen, hvis de først vendte sig om og slap dem. Eleverne genkendte hurtigt deres egne og deres klassekammerraters prototyper og blev generelt positivt overraskede. De virkede stolte over det, de havde lavet.

"Hoppe-tasten", F, voldte børnene en del problemer. De havde forinden fået at vide, at de skulle bruge F-tasten, men de fleste kom alligevel til at forsøge sig med mellemrumstasten gentagne gange. Desuden var højden af et hop sat for lavt, hvilket resulterede i at det ikke var muligt at komme op af vandet i Udsigten igen, hvis man faldt $i$.

Efterfølgende blev eleverne spurgt ind til deres oplevelse. En elev synes, det kunne være "fedt", hvis alt det de lavede i billedkunst kunne komme ind i en Oculus Rift verden. Flere elever blev positivt overraskede over de ting, de havde lavet. En gruppe mente endda, at simulationen kunne udgives til salg i butikker. Eleverne var især begejstrede for stadionet, fordi man kunne gå ind i det og der var "... flere ting at opdage". Desuden blev det foreslået, at simulationen skulle være mere levende - tingene skulle 
bevæge sig. Man skulle kunne se blæsten i palmerne, is-langhalsene skulle bevæge sig og der skulle være animerede spillere og publikum på stadion.

Eleverne blev spurgt ind til, hvad der skulle være anderledes, hvis simulationer som deres skulle bruges i skolen. Hertil blev der svaret, at simulationerne skulle være mere korrekte og levende.

Eleverne blev også spurgt om, de synes, Oculus Rift kunne bruges i billedkunstundervisningen, som de havde gjort det. Det var der bred enighed om, at den kunne. Eleverne havde, ifølge dem selv, lært meget om de ting, de havde bygget, fordi de havde læst om dem på nettet og de havde lært om Oculus Rift.

De to elever, der havde besøgt Keopspyramiden, synes simulationen gav et godt indtryk af, hvor stor pyramiden var i virkeligheden, men de synes ikke, den var lavet detaljeret nok og at det var ærgerligt, man ikke kunne komme ind i pyramiden i simulationen.

\section{Diskussion}

I det efterfølgende diskuteres og evalueres designforløbet, Oculus Rift i relation til tilstedeværelse, teknologien i projektet, læreprocesser, billedkunst, design og teknologi.

\section{Design centreret læreproces: Elever som engagerede informanter og} designpartnere

Eleverne deltog i særlig grad i rollen som informanter, idet de gav input og feedback undervejs i designforløbet (Druin, 2010). Eleverne observeredes med eksisterende rutsjebanesimulationer, de gav input om hvad de syntes god undervisning var, og hvordan teknologien kunne indgå i denne, input i form af Mindmaps, fysiske 3D-prototyper, evaluering af digitale prototyper. Man kan desuden argumentere for at eleverne også i nogen udstrækning var designpartnere, idet de deltog i alle faser i udviklingsarbejdet lige fra for-analyse, udviklingen af 3D-prototyper og evaluering af de virtuelle prototyper. Ifølge Druin, skal man som designpartner deltage på lige fod igennem hele udviklingsforløbet (Druin, 2010: 3). Der var dog designaktiviteter som børnene ikke deltog i på lige fod, fx planlægning, tidsforbrug, prioritering aktiviteter, koordinering af designforløb etc. Læreren kan derimod beskrives som designpartner og "interactor" $\mathrm{i}$ projektet, hvilket tilførte projektet værdi. Hvis vi havde valgt at anvende et eksisterende læremiddel fx fra CyArk (Kacyra, 2015), så havde elevernes rolle i større udstrækning været brugere eller testere. Idet de så blot skulle observeres i forbindelse med anvendelse af eksisterende produkt. I dette projekt var børnene aktive deltagelse dog mere vidtgående, idet de var med fra for-analyse og i alle faser og derfor deltog som informanter og designpartnere. 
Som designpartnere og informanter tænkte eleverne aktivt med i udviklingsprocessen og var med til at påvirke udviklingen af det digitale produkt. Elever som informanter eller designpartnere kan føle sig "empowered", idet de voksne lytter til, hvad de har at sige om de nye teknologier. De făr oplevelser, hvor de kan bidrage med deres mening og blive taget alvorligt af voksne. Dette kan medvirke til at opbygge selvtillid hos børn fagligt og socialt (Druin, 2002, s. 21). Druin beskriver dette som en design-centreret læreproces.

Koblingen af tilstedeværelse i den fysiske og virtuelle verden Afprøvningen af Oculus Rift med rutsjebanesimulationen virkede meget livagtigt på eleverne. De bevægede hovedet naturligt til højre og venstre og op og ned for at få det hele med. Dette kan beskrives som fysisk proprioceptiv tilstedeværelse, som bygger på at være i stand til at sensomotorisk og kropsbevidst at opfatte ens nærmeste omgivelser, orientere sig og bevæge sig i forhold til dette (Waterworth og Riva, 2014, s. 15). Nogle af eleverne holdt desuden fast i sædet, hvilket kan forbindes med kerne-tilstedeværelse, der bygger på hvordan man forstår og opfatter sine stadigt skriftende omgivelser i relation til ens erfaringer. Disse elever ved måske fra tidligere rutsjebaneture, at det føles mere sikkert at holde sig fast til sædet. Disse to typer af tilstedeværelse medvirkede til at gøre rutsjebaneturen særlig livagtig. I forbindelse med testen af elevernes egne prototyper var der også eksempler på disse typer af tilstedeværelse. Et eksempel på stærk fysisk proprioceptiv tilstedeværelse var når eleverne fremhævede at de kunne gå ind i stadionnet, springe ned på havets bund eller fornemme Keopspyramidens kolosale størrelse i relation til deres egn størrelse.

Styringen med WASD-tasterne fremmede dog ikke i første omgang den fysiske fornemmelse af tilstedeværelse, idet eleverne skulle vende sig til at trykke på tasterne i blinde.

På kerne- og udvidet reflekteret tilstedeværelsesniveau, var der en konflikt mellem børnenes erfaringer med fx deltaljerne på Keopspyramiden, og det de erfarede i Oculus Rift, hvilke begrænsede deres fornemmelse af tilstedeværelse. På udvidet reflekteret niveau, forholdt de sig mere som designere, der havde visioner for, hvordan simulationen kunne videreudvikles og forbedres.

\section{Billedkunst og teknologi}

I dette projekt har eleverne fremstillet rumlige figurer og installationer, som har haft en særlig betydning i deres liv, fx noget de har oplevet på en rejse, et sted de gerne vil besøge i fremtiden eller et tema fra undervisningen, som har gjort et særligt indtryk.

Deres rumlige installationer og figurer, blev samlet og udstillet Virtual Reality. Derefter "besøgte" de Grønland, Keopspyramiderne og det berømte 
stadion i Virual Reality. Her fik de et nyt perspektiv på deres kreationer, idet de her kunne gå ind i stadionet, selvom det i den fysiske verden ikke var større end en mælkekasse. Dette arbejde med rumlige installationer kan betegnes som æstetiske læreprocesser, hvor eleverne opnåede tilfredsstillelse ved at blive bedre til at udtrykke sig visuelt og ved at indgå i de visuelle og virtuelle begivenheder, jævnfør eleverne elevernes kommentarer i afsnittet Prototyperne omsættes til den Virtual Reality og testes. Dette er netop et fokus område i vejledningen for billedkunstfaget (Emu - Vejledning for faget billedkunst, 2014). Eleverne udbyggede deres udtryksrepertoire og tilegnede sig faglige begreber om Virtual Reality, 3Dscanning og størrelsesforhold, som vil gøre det muligt for eleverne hen ad vejen at udvikle personlige måder at udtrykke sig på.

\section{Rumlige former og kropslighed}

Arbejdet med de rumlige installationer gav rige muligheder for at eksperimentere med et bredt udbud af materialer, herunder pap, flamingo, sand, træ, lim, maling ståltråd og stof. Arbejdet med rumlig former, modellering, sammenføjning og maling af prototyper gav eleverne mange taktile og kinæstetiske erfaringer. Der blev udformet arkitektoniske bygningsværker i form af pyramider, igloer og stadion. Der blev formet naturområder i form af Grønland, Afgrunden og havets dyb. De arbejdede her med størrelsesforhold og hvordan forskellige elementer kunne positioneres i forhold til hinanden. Ifølge Vejledning for billedkunst er det vigtigt, at eleverne får bedre mulighed for at møde og opleve arkitekturen og arbejde alsidigt med modellering af rumlig former (Emu - Vejledning for faget billedkunst, 2014).

I den virtuelle dimension fik eleverne et andet perspektiv på den fysiske oplevelse, de kunne ikke længere mærke sandet eller flamingoen - men de kunne flyve hen over den. De oplevede endvidere størrelsesforholdene som forandrede.

\section{Erfaringsbaseret og oplevelsesrig læring}

I projektet arbejdede eleverne aktivt med at udvikle ideer og konstruere fysiske rumlige prototyper. Derefter oplevede de deres prototyper i et virtuelt perspektiv. Denne oplevelse kan kobles til erfaringsbaserede læreprocesser, som det beskrives af fx Kolb (1984) og Illeris (2006). Kolb definerer læring som en proces, hvor viden skabes igennem transformation af oplevelser (Kolb, 1984 s. 38). Man lærer altså ikke alene af oplevelsen, men igennem en transformation af denne. Grundlaget for transformationen dannes ifølge Kolb (1984) af elementerne refleksion og abstrakt begrebsliggørelse, aktiv eksperimenteren og så altså oplevelser og erfaringer. Kombination af disse udgør en læreproces, hvorigennem tilpasning af viden og ny viden opstår. Projektet indeholdt disse elementer: (1) Aktiv eksperimenteren igennem udvikling af fysiske prototyper; (2) oplevelse, se deres prototyper i virtual reality; (3) Refleksion over 
forvandlingen af prototyperne og (4) Abstrakt begrebslig forståelse af virtual reality igennem dialog og deres egen oplevelse. Erfaringsbaseret læring bliver således, den sekventielle proces af aktiv eksperimenteren, oplevelse, refleksion og abstrakt og begrebsliggørelse. Kolb var inspireret af mange af det nittende århundredes læringsteoretikere bl.a. Piaget, som havde fokus på individets stadige tilpasning til omgivelserne, som Kolb måske lidt for ubekymret sammenstillede (Illeris, 2006). Vi vil dog fremhæve Kolbs inspiration fra Lewin (1947), som står fadder til aktionsforskningsbegrebet, hvor forskere og praktikere arbejder sammen. Lewin tænkte også læring i cirkulære sekvenser af: (1) ide og planlægning; (2) aktion, hvor man igennem aktiv deltagelse gennemførte planen og (3) Evaluering af aktionen, hvad lærte man i aktionen? - hvordan passer det med teorien? Efter evalueringen vil man revidere sin ide og gennemføre en revideret aktion. Her igennem bliver læringen en proces, som den lærende selv kontrollerer igennem aktiv eksperimenteren, refleksion og nye forandrende ideer. Designprocessen i dette projekt, hvor læreren, forskeren og eleverne deltog aktiv kan netop beskrives som aktionsforskning. Og hvis vi kan få eleverne til at tænke i aktionssekvenser, så har de et godt værktøj til at omsætte deres ideer til virkelighed og konstant optimere disse.

Papert arbejder ligeledes med erfaringsbasseret læring og er særligt kendt for sin situerede konstruktionisme. Det at elever bygger noget i den virkelige verden, der, for dem, er meningsfuldt kan, ifølge Papert, øge motivationen og læringen (Papert, 1993). Eleverne havde selv valgt, hvad de ville bygge, hvilket også virkede til at afspejle sig i deres arbejde; de arbejdede meget koncentreret, søgte på eget initiativ oplysninger om det de byggede på nettet, bad om at få lov at arbejde i pauserne og læreren berettede om, at eleverne havde arbejdet mere koncentreret og effektivt under projektet end normalt.

\section{Evaluering af den teknologiske platform}

Oculus Rift præsenterer en mulighed for at samle og udforske elementer fra den fysiske eller virtuelle verden på en ny og anderledes måde. Denne del af den teknologiske plaform er umiddelbar tilgængelig.

For at det kan lade sig gøre skal de fysiske installationer dog indscannes. Dette var en større opgave end først antaget, og det var en opgave, der skulle løses af en teknisk ekspert. Der blev afprøvet simple scannere som 123DCatch, men disse fungerede ikke optimalt i projektperioden (Autodesk - 123D Catch, 2015). Derfor blev alle de fysiske prototyper fotograferet fra alle sider og rekonstrueret med Blender og Unity. En scanner i stil CyArk's ville have forenklet denne proces. Indscanning og præsentationsdelen vil som nævnt for nuværende kræve en teknisk ekspert med viden om Unitity, Blender og 3D-scanning. 


\section{Opsamling og konklusion}

Denne artikel udforsker hvordan læringscentrerede designprocesser og virtual reality kan understøtte læring i billedkunst i 5. klasse. Oculus Rift headsettet opfanger brugerens hovedbevægelser og anvender disse til a navigere rundt i en virtuel verden.

Læringspotentialerne kan først og fremmest beskrives igennem: (1) Design centrerede læreprocesser og (2) kombinationen af tilstedeværelse i fysiske og virtuelle verden.

(1) Design centrerede læreprocesser. Eleverne indgik i en designcentreret læreproces, hvor de fungerede som engagerede informanter og designpartnere. Eleverne indgik i alle designfaser fra for-analyse, idegenerering, fysisk produktudvikling, test af virtuelle prototyper og evaluering af projektet. Derudover fik de erfaring med kreative designprocesser og egenproduktioner i den fysiske og virtuelle verden. De fik en større forståelse af teknologi, og hvordan de selv kan deltage i itdesign.

Eleverne fik konkrete erfaringer med alle led i designprocessen. De oplevede at kunne bidrage med deres mening og de blev taget alvorligt af voksne. Hvilket kan medvirke til at opbygge deres selvtillid fagligt og socialt.

(2) Kombinationen af tilstedeværelse i fysiske og virtuelle verden. Det helt specielle i dette projekt var muligheden for at kombinere tredimensionelle fysiske prototyper med ditto virtuelle prototyper. Dette gav eleverne en unik mulighed for arbejde taktilt og fysisk med at udforme bygninger og rumlige modeller i miniformat for, derefter at besøge dem i den virtuelle verden i den størrelse de skulle have haft. Det gav børnene mulighed for at springe ned på havets bund eller udforske Grønland eller pyramiderne. Fagligt fik eleverne konkrete erfaringer med målestoksforhold i 3D både i den fysiske og virtuelle verden, kobling af fysisk tilstedeværelse i den fysiske og virtuel verden, og Virtuel Reality teknologi.

De gjorde sig konkrete erfaringer med, hvad det vil sig at være til stede og fordybet i Virtuel Reality. De oplevede på fysisk tilstedeværelsesniveau, hvordan de kunne bruge hovedbevægelser til at navigere rundt i den virtuelle tredimensionelle verden. På kerne og udvidet tilstedeværelsesniveau oplevede teknologiens styrker og svagheder, som de kan tage med i deres forståelse af den digitale verden.

Teknologien, som anvendtes i dette projekt til at scanne fysiske tredimensionelle prototyper ind i den virtuelle verden, er dog endnu ikke 
helt moden. Så fremtidige projekter vil kræve et særligt fokus på, hvordan man kan forenkle denne proces.

Elevcentrerede designprocesser er et godt værktøj når der skal udvikles ny teknologi og nye anvendelser af eksisterende teknologi, man får et ekstra værktøj til at forstå og arbejde med eleverne i designprocessen.

\section{Perspektiver}

Når man anvender virtuel reality er man oftest isoleret; man har et headset for øjnene, høretelefoner på og spillene/simulationerne er ofte singleplayer - man bliver afskåret fra den virkelige verden. Med nye billige alternativer, fx Google Cardboard, er det mere sandsynligt, at skoler anskaffer sig hele klassesæt, hvilket muliggør (mere) social læring. Der findes allerede få mulitiplayer apps, bl.a. Riftmax Cinema (Digital Trends, 2015), der gør det muligt at se film og videoer sammen virtuelt. En nyere app, Converge (Digital Trends, 2015), gør det muligt at "være sammen" virtuelt. I app'en er man repræsenteret af en selvvalgt avatar, som afspejler ens hovedbevægelser i virkeligheden i det virtuelle rum. I rummet kan man interagere med andre og kommunikere via tale.

Ift. til billedkunst kunne det være interessant at udvikle en app, der kunne tage elever og lærere på virtuelle udflugter. Man kunne forestille sig at eleverne analyserer forskellige kendte værker og efterfølgende "besøger" disse. Har man fx arbejdet med De syv underværker, kan læren efterfølgende give eleverne en guidet tur, hvor de kan bevæge sig omkring og ind i værkerne og derigennem få en bedre forståelse for værkernes fysiske fremtræden. Ved at eleverne og læreren er inde i samme simulation og kan interagere der, bevæger man sig væk fra den isolation, der oftest er knyttet til virtual reality. Det sociale aspekt, som bl.a. Etienne Wenger fremhæver som essentielt for læring (Wenger, 2001), løftes.

Augmentet reality er anden måde at undgå at eleverne arbejder isoleret. Her kan eleverne se de omgivelser, de er i i virkeligheden, tilføjet virtuelle objekter. Oculus Rift har ikke med denne mulighed, men flere har eksperimenteret med at sætte to kameraer på masken (for at få et stereo billede), hvilket fungerer fint (Wsteptoe, 2013). Google Cardboard, der som nævnt anvender en mobiltelefon, bruger telefonens kamera og virker derfor til augmentet reality out-of-the-box, dog uden stereo-syn. Det gør det muligt for læreren at vise "hologrammer" for eleverne i klasseværelset. Det kunne være en skulptur, de taler om i undervisningen, som læreren kan finde frem. I og med, at der anvendes augmentet reality vil eleverne kunne se læreren ved siden af, mens de studerer skulpturen. 


\section{Referencer}

Allison, D. \& Hodges, L. F. (2000). Virtual reality for education?. Proceedings of the ACM symposium on Virtual reality software and technology(VRST '00), 160-165. Doi=10.1145/502390.502420

Bertel, L.B. \& Rasmussen, D.M. (2013). On Being a Peer: What Persuasive Technology for Teaching Can Gain from Social Robotics in Education. International Journal of Conceptual Structures and Smart Applications (IJCSSA), 1(2), 58-68.

Blikstein, P. (2013). Digital Fabrication and 'Making' in Education: The Democratization of Invention. FabLabs: Of Machines, Makers and Inventors. Bielefeld: Transcript Publisher

Bolter, J. D. and Grusin, R. (2000). Remediation. Understanding New Media. New Media. MIT Press

Druin, A. (1999). Cooperative Inquiry: Developing New Technologies for Children with Children. CHI'99, Pittsburgh, PA, USA, May 15-20, s. 592599

Druin, A. (2002). The Role of Children in the Design of New Technology. Behaviour and Information Technology (BIT) 21(1), pp. 1-25. DOI: 10.1080/01449290110108659

Dourish, P. (2001). Where The Action Is: The Foundations of Embodied Interaction. MIT Press

Ejsing-Duun, S. \& Karoff H. S. (2015). Creativity and Playfulness: Producing Games as a Pedagogical Strategy. ECGLB 2015 (Draft)

Illeris, K. (2006). David Kolbs teori om læringsstile. I Læringens og tænkningens stil: En antologi om stilteorier. (1 ed.). København: Billesø.

Iversen, O., Brodersens, C. (2006). Building a BRIDGE between children and users: a socio-cultural approach to child-computer interaction.

Jessen, C. et al, (2003). Børnekultur, leg, læring og interaktive medier. The changing face of children's play culture. Lego Learning Institute 2003. http://www.carsten-jessen.dk/LegOgInteraktiveMedier.pdf (senest lokaliseret den 030608)

Kolb, D.A. (1984). Experiential learning: experience as the source of learning and development. Englewood Cliffs, NJ: Prentice Hall.

Lewin, K. (1946). Action Research \& Minority Problems. Journal of Social Issues 2, no. 4 (1946): 34-46.

Majgaard, G. (2015). Multimodal Robots As Educational Tools In Primary And Lower Secondary Education. I The 9th International Conference on Interfaces and Human Computer Interaction 22 - 24 July 2015, IADIS Multi Conference on Computer Science and Information Systems. (s. 2734). International Association for Development, IADIS. Majgaard_IHCI_2015 
Larsen, L. J. \& Majgaard, G. 2014. A model for understanding the game design process: design paradigm, design space, problem-based creativity. proceeding at the Designs for Learning Conference. link

Majgaard, G., Hansen, J. J., Bertel, L. B. \& Pagh, A. dec. 2014. Fra digitalt design til fysisk udtryk - anvendelse at 3-d-printere og NAO-robotter i folkeskolen. Mona. 2014, 4, s. 7-26 link

Majgaard, G. \& Bertel, L. B. 2014. Initial Phases of Design-based Research into the Educational Potentials of NAO-Robots. ACM/IEEE International Conference on Human-Robot Interaction. s. 238-239 link

Majgaard, G. 2014. Teaching Design of Emerging Embodied Technologies. Human-Computer Interfaces and Interactivity: Emergent Research and Applications. IGI global, Kap. 11, s. 188-206 Teaching Design of Emerging Embodied Technologies 2014

Majgaard, G. 2014. The playful and reflective game designer. Electronic Journal of E-Learning. 12, 3, s. 271-280 link

Majgaard, G. 2013. Creating Games in the Classroom: from native gamers to reflective designers. Proceeding of The 7th European Conference on Games Based Learning (ECGBL 2013). Porto, Portugal. UK: Academic Conferences and Publishing International Limited, s. 253-258

Malaby, T. M. (2009). Making virtual worlds: Linden Lab and Second Life. Ithaca Cornell University Press 2009

Mantovani, F. (2003). "VR learning: potential and challenges for the use of 3D environments in education and training". In Giuseppe Riva \& Carlo Galimberti (Eds.), Towards cyberpsychology: mind, cognitions and society in the internet age (pp. 207-225). Amsterdam: IOS Press. Mayer, R. E.

Murray, J.H. (1997). Hamlet on the Holodeck: The Future of Narrative in Cyberspace (New York: The Free Press, 1997), 324 pp. ISBN 0-68482723-9)

Nielsen, J., Jessen, C., \& Bærendsen, N. K. (2008). RoboMusicKids - Music Education with Robotic Building Blocks. Proceedings of the 2nd IEEE International Conference on Digital Game and Intelligent Toy Enhanced Learning (DIGITEL), (pp. 149-156).

Papert, S. (1993). Mindstorms Children, Computers, and Powerful Ideas. Basic Books.

Resnick, M. et al. (2009a). Scratch: Programming for All. Communications of the ACM, November 2009, 52(11), s. 60-67.

Resnick, M. et al. (2009b). Growing up Programming: Democratizing the Creation of Dynamic. Interactive Media.

Rizzo A. et al (2014). Virtual Reality Exposure Therapy for Combat-Related Posttraumatic Stress Disorder. Published by the IEEE Computer Society. 
Salen, K. \& Zimmerman, E. (2004). Rules of Play - Game Design Fundamentals. MIT Press

Turkle, S. (2010) Alone together: why we expect more from technology and less from each other. Basic Books.

Waterworth J. \& Riva G. (2014). Feeling Present in the Physical World and in Computer-Mediated Environments. Palgrave Macmillan. ISBN: 9781137431677 DOI: 10.1057/9781137431677

Wenger E. In Illeris, K. (2001) Lærings teorier: - 6 aktuelle forståelser. Roskilde Universitetsforlag. Chapter 3, Social læringsteori; p.61-79.

Links

About the CyArk 500 Challenge (2015). Retrieved July 10, 2015 from http://archive.cyark.org/.

Afgrunden (2006). Retrieved July 10, 2015 from, http://www.danskebjerge.dk/vissenbjerg.htm.

Augmented Reality Apps (2015). Retrieved July 10, 2015, from http://www.iphoneness.com/iphone-apps/best-augmented-realityiphone-applications/\# .

Autodesk - 123D Catch (2015). Retrieved July 10, 2015, from http://www.123dapp.com/catch. Senest downloadet 10.7.2015.

Blender (2014). Retrieved May 15, 2014, from http://www.blender.org/

Digital Trends (2015). Digitaltrends.com - Virtual Reality is Lonely, but it Doesn't Have to Be. Retrieved August 16, 2015, from http://www.digitaltrends.com/computing/facebook-social-virtualreality/

Drummound, K. Virtual Rx; how Oculus Rift could revolutionize mental health (2013). Retrieved August 16, 2015, from http://www.theverge.com/2013/4/22/4251926/oculus-rift-virtualreality-therapy-mental-health

Fællesmål og læseplan for faget billedkunst (2015). Retrieved July 10, 2015, from http://www.emu.dk/modul/billedkunst-f\%C3\%A6llesm\%C3\%A5l-1\%C3\%A6seplan-og-vejledning\# http://www.emu.dk/sites/default/files/L\%C3\%A6seplan\%20for\%20fa get $\% 20$ billedkunst.pdf.

Emu - Vejledning for faget billedkunst (2014). Retrieved July 16, 2015, from http://www.emu.dk/modul/vejledning-faget-billedkunst.

Google Cardboard (2015). Retrieved July 10, 2015, from https://www.google.com/get/cardboard/ 
Johnson, B. How the Oculus Rift Works (2014). Retrieved July 10, 2015, from http://electronics.howstuffworks.com/oculus-rift5.htm

Kacyra, B. Ancient wonders captured in 3D (2011). Retrieved July 16, 2015, from http://www.ted.com/talks/ben_kacyra_ancient_wonders_captured_in_3 d

Lorry Rider (2013). Retrieved May 16, 2014, from https://developer.oculusvr.com/forums/viewtopic.php?f=28\&t=6367.

[Markiplier]. (2013, September 21). SCARIEST OCULUS RIFT GAME: Dreadhalls Oculus Rift Horror (with Ending!). [Video File]. Retrieved May 16, 2014, from https://www.youtube.com/watch?v=fl7fz__6B-4

Microsoft Hololens (2015). Retrieved July 10, 2015, from https://www.microsoft.com/microsoft-hololens/en-us

Plafke, J. Walk on Mars using the Oculus Rift and Omni treadmill (2013). Retrieved July 16, 2015, from http://www.extremetech.com/extreme/163189-walk-on-mars-usingthe-oculus-rift-and-omni-treadmill

Riftenabled Dreadhall (2014). Retrieved May 16, 2014, from http://www.riftenabled.com/admin/app/408

Wiki Augmented Reality (2015). Retrieved July 10, 2015, from https://en.wikipedia.org/wiki/Augmented_reality

Oculus Rift (2015). Retrieved July 10, 2015, from https://www.oculus.com/en-us/. Senest downloadet 10.7.2015.

Oculus Rift Development Kid (2013). Retrieved May 16, 2014, from http://blogs.windows.com/windows/b/extremewindows/archive/201 $3 / 12 / 11 /$ hands-on-with-oculus-rift-virtual-reality-developmentkit.aspx

Unity (2014). Retrieved May 16, 2014, from https://unity3d.com/

[Unity]. (2013, October 30). Unite 2013 - Step into the Game with Oculus Rift and Unity 4.2. [Video File]. Retrieved May 16, 2014, from https://www.youtube.com/watch?v=R2kmi103tpU.

Virtuix Omni (2015). Retrieved May 16, 2014, from http://www.virtuix.com/

Virtuix Omni Treadmill And Oculus Rift Playing Counter-Strike (2014). Retrieved from http://www.geeky-gadgets.com/virtuix-omni-treadmilland-oculus-rift-playing-counter-strike-video-14-05-2014/

[wsteptoe]. (2013, November 20). Stereo camera rig and augmented reality showcase. [Video File]. Retrieved August 16, 2015 from https://www.youtube.com/watch?v=Bc_TCLoH2CA 